\title{
The development potential of bovine embryo co-culture with Vero and Vero/BRL cells*
}

\section{A.M. Duszewska ${ }^{1}$, J. Wojdan ${ }^{2}$, W. Gawron ${ }^{2}$, E. Wenta-Muchalska ${ }^{1}$, B. Waś ${ }^{1}$, A. Wiśniewska ${ }^{1}$ and Z. Reklewski ${ }^{2}$}

\author{
Institute of Genetics and Animal Breeding, Polish Academy of Sciences, \\ ${ }^{1}$ Department of Experimental Embryology, \\ ${ }^{2}$ Department of Cattle Genetics and Breeding \\ Jastrzębiec, 05-552 Wólka Kosowska, Poland
}

(Received 15 May 2007; revised version 9 July 2007; accepted 6 September 2007)

\begin{abstract}
The objective of this study was to evaluate the effect of two bovine embryo co-culture systems on calving rates. The embryos were co-cultured with Vero or Vero/BRL cells (mixed co-culture) until the blastocyst stage. A higher percentage of blastocysts was observed on Vero/BRL cells, $42.85 \%$, compared with $30.41 \%$ on Vero cells $(\mathrm{P} \leq 0.05)$. The blastocysts from Vero/BRL and Vero cells were transferred to recipients. A higher rate of calving was obtained after transfer of embryos co-cultured with Vero cells (37.50\%), compared with Vero/BRL cells $(13.16 \%)(\mathrm{P} \leq 0.01)$. A greater loss of pregnancy after transfer of embryos co-cultured with Vero/BRL cells was observed between 35 and 65 days. All calves were born naturally, healthy, and with normal weight. Vero cells better support cattle prenatal development than Vero/BRL cells. Probably Vero/BRL cells lead to epigenetic modifications that are responsible for early foetal resorption.
\end{abstract}

KEY WORDS: Vero, BRL, embryos, co-culture, cattle

\footnotetext{
${ }^{*}$ Supported by the State Committee for Scientific Research, Grant No. 2PO6D05228

${ }^{1}$ Corresponding author: e-mail: duszewskaanna@hotmail.com
} 


\section{INTRODUCTION}

In vitro production of bovine embryos has applications both in cattle breeding and in biotechnology for cloning, transgenics and creation of chimeras (Gordon, 2003). There are three frequently used systems for culture of bovine embryos from zygote to blastocyst. The most common system relies on sequential culture in several different media: SOFaa (Holm et al., 1999), KSOM (Liu and Foote, 1995), CR1 (Rosenkranz and First, 1994) and CZB (Rehman et al., 1994). Another system employs co-culture with different kinds of cells such as Vero cells (Pegoraro et al., 1998), BRL cells (Reed et al., 1994) or a combination of both (so-called "mixed co-culture") (Duszewska et al., 2000). A third system uses medium preconditioned by the above cells (Maed et al., 1996), but this system is rarely used. All of these systems have similar advantages and disadvantages (Gordon, 2003, review: Orsi and Reischl, 2007). Although they are well-established, there is a need to determine the effect of each system on the developmental potential of embryos by transfer to recipients (Hansen, 2006).

In this study, two co-culture systems were compared to determine the developmental potential of bovine embryos after transfer to recipients. The first system was based on co-culture of embryos with Vero cells and the second coculture with both Vero and BRL cells (mixed co-culture).

Vero is a kidney epithelial cell line from the green monkey (Cercopithecus aetiops). The cells are derived from the kidney, which shares a common mesodermal origin with the genital tract. BRL cells are rat liver epithelial and parenchyma-like cells (Rattus norvegicus), which are of endodermal origin.

Bovine embryos have been successfully co-cultured with Vero cells, but the percentage reaching the blastocyst stage is lower than that of embryos co-cultured with BRL cells (Duszewska et al., 2000). According to some authors, the pregnancy rate after transfer of embryos developing on Vero cells is high (Menck et al., 1997). Hence, Vero and BRL cells were combined in an effort to enrich the environment for embryonic development and also to improve prenatal development.

\section{MATERIAL AND METHODS}

\section{In vitro maturation of bovine oocytes}

Bovine ovaries were obtained from a slaughterhouse and transported within $2 \mathrm{~h}$ to the laboratory in phosphate-buffered solution (PBS) with $100 \mathrm{IU} / \mathrm{ml}$ streptomycin and $100 \mathrm{IU} / \mathrm{ml}$ penicillin at approximately $30^{\circ} \mathrm{C}$. Cumulus-oocyte complexes (COCs) were collected by aspiration from follicles $(2$ to $6 \mathrm{~mm}$ in diameter) using a syringe with an 18-gauge needle and an air pump system. COCs 
were washed 3 times in TCM199 buffered with $25 \mathrm{mM}$ Hepes supplemented with $10 \% \mathrm{FBS}, 50 \mu \mathrm{mg} / \mathrm{ml}$ gentamicin sulphate, $100 \mathrm{IU}$ penicillin and $50 \mu \mathrm{mg} /$ $\mathrm{ml}$ streptomycin, and adjusted to $\mathrm{pH}$ 7.4. The COCs were matured in TCM199 buffered with $25 \mathrm{mM}$ Hepes supplemented with $10 \% \mathrm{FBS}, 0.02 \mathrm{IU} / \mathrm{ml} \mathrm{pFSH}$, $1 \mu \mathrm{mg} / \mathrm{ml} 17 \beta \mathrm{b}$-oestradiol, $0.2 \mathrm{mM} \mathrm{Na}$ pyruvate and $50 \mu \mathrm{mg} / \mathrm{ml}$ gentamicin sulphate. A group of COCs (20 immature oocytes) was placed in one well of a 4-well dish and matured in $450 \mu \mathrm{ml}$ TCM199 buffered with $25 \mathrm{mM}$ Hepes and supplemented with $10 \% \mathrm{FBS}, 0.02 \mathrm{IU} / \mathrm{ml} \mathrm{pFSH}, 1 \mu \mathrm{mg} / \mathrm{ml} 17 \beta \mathrm{b}$-oestradiol, 0.2 $\mathrm{mM}$ Na pyruvate and $50 \mu \mathrm{mg} / \mathrm{ml}$ gentamicin sulphate. The COCs were matured for $24 \mathrm{~h}$ at $38.5^{\circ} \mathrm{C}$ in $5 \% \mathrm{CO}_{2}$ in humidified air (Marguant-Le Guienne et al., 1989).

In vitro fertilization of bovine oocytes

Frozen spermatozoa obtained from a single bull were thawed in a waterbath $\left(37^{\circ} \mathrm{C}\right)$, centrifuged $(200 \mathrm{xG})$ for $10 \mathrm{~min}$, and resuspended in $2 \mathrm{ml}$ Sp-TALP medium containing $6 \mathrm{mg} / \mathrm{ml}$ BSA fraction V adjusted to $\mathrm{pH}$ 7.4. Spermatozoa were prepared by the "swim-up procedure" (Parrish et al., 1986). After maturation, COCs were washed 3 times in fertilization medium Fert-TALP supplemented with $6 \mathrm{mg} / \mathrm{ml} \mathrm{BSA} \mathrm{FAF,} 0.2 \mathrm{mM} \mathrm{Na}$ pyruvate and $50 \mu \mathrm{mg} / \mathrm{ml}$ gentamicin sulphate. Groups of matured oocytes (10 COCs) were placed in 4-well dishes in $450 \mu \mathrm{ml}$ Fert-TALP supplemented with $6 \mathrm{mg} / \mathrm{ml}$ BSA FAF, $0.2 \mathrm{mM}$ Na pyruvate, $50 \mu \mathrm{mg} /$ $\mathrm{ml}$ gentamicin sulphate, $20 \mu \mathrm{mM}$ penicillamine, $10 \mu \mathrm{mM}$ hypotaurine, $1 \mu \mathrm{mM}$ epinephrine and $2 \mu \mathrm{mg} / \mathrm{ml}$ heparin. Spermatozoa were used at a final concentration of $1 \times 10^{6} / \mathrm{ml}$. The COCs and spermatozoa were co-cultured for $18 \mathrm{~h}$ at $38.5^{\circ} \mathrm{C}$ in $5 \% \mathrm{CO}_{2}$ in humidified air (Marguant-Le Guienne et al., 1989).

In vitro culture of bovine embryos

At $20 \mathrm{~h}$ post-insemination, the cumulus cells were removed and the zygotes washed in Menezo B2 medium (ART of CCD) supplemented with 10\% FBS (GIBCO) and placed in 40- $\mu \mathrm{ml}$ drops of Menezo B2 medium supplemented with $10 \%$ FBS under mineral oil. The zygotes were randomly allocated to one of the experimental groups: Vero and Vero/BRL.

Embryos were co-cultured until day 7, i.e. $168 \mathrm{~h}$ post insemination, at $38.5^{\circ} \mathrm{C}$ in $5 \% \mathrm{CO}_{2}$ in humidified air. During culture the medium was renewed twice (at 48 h, $20 \mu \mathrm{ml}$ of medium was removed and $20 \mu \mathrm{ml}$ of Menezo B2 supplemented with $10 \%$ FBS was added; and at $144 \mathrm{~h}, 20 \mu \mathrm{ml}$ of medium was removed and $20 \mu \mathrm{ml}$ of Menezo B2 without serum was added). 


\section{Culture of Vero and BRL cells}

Frozen samples of established Vero and BRL cell lines (ATCC, Maryland, USA) were used to prepare respective Vero cell monolayers and BRL cell monolayers. Cell lines were thawed and cells seeded at a concentration of $1 \times 10^{6} / \mathrm{ml}$ in $25 \mathrm{~cm}^{2}$ culture flasks in the TCM 199 medium supplemented with $10 \% \mathrm{FBS}, 50 \mu \mathrm{mg} / \mathrm{ml}$ gentamicin sulphate, $100 \mathrm{IU}$ penicillin, and $50 \mu \mathrm{mg} / \mathrm{ml}$ streptomycin and cultured at $38.5^{\circ} \mathrm{C}$ in $5 \% \mathrm{CO}_{2}$ in humidified air. The medium from both the Vero and BRL cultures was removed and replaced with fresh medium after 2 days. BRL cells (after 4 days of culture) and Vero cells (after 7 days of culture) were trypsinized ( $0.25 \%$ trypsin) for passages to prepare the monolayers and microdrops for culture of embryos.

\section{Preparation of Vero cells in drops under mineral oil}

Vero cells were placed at a concentration of $2 \times 10^{3} / 10 \mu \mathrm{ml}$ into a microdrop (40 $\mu \mathrm{ml}$ ) of Menezo B2 (ART of CCD) supplemented with 10\% FBS under mineral oil and cultured at $38.5^{\circ} \mathrm{C}$ in $5 \% \mathrm{CO}_{2}$ in humidified air. The next day, the zygotes were placed in a microdrop.

\section{Preparation of Vero/BRL cells in drops under mineral oil}

Vero cells were first placed at a concentration of $1 \times 10^{3} / 10 \mu \mathrm{ml}$ into a microdrop (40 $\mu \mathrm{ml}$ ) of Menezo B2 (ART of CCD) supplemented with 10\% FBS under mineral oil. After $30 \mathrm{~min}$, BRL cells were added at the same concentration to the same drop, which was then cultured at $38.5^{\circ} \mathrm{C}$ in $5 \% \mathrm{CO}_{2}$ in humidified air. One day later, the zygotes were placed in the microdrop.

\section{Embryo transfer and offspring evaluation}

Oestrus synchronization of the recipients was induced by injecting $2 \mathrm{ml}(0.5 \mathrm{mg})$ of the prostaglandin $\mathrm{F}_{2 \alpha}$-analogue, Cloprostenol (Bioestrovet-Vetoquinol, Gorzów, Poland) every 11 days. Seven to eight days after the standing heat, one fresh embryo was transferred to the uterine horn ipsilateral to the ovary displaying a corpus luteum. Embryos were transferred to recipients in Embryo Transfer Medium (BioLife Transfer Medium, Agtech Inc., USA). Recipients were monitored daily for heat behaviour and examined by ultrasound after 5 weeks and then monthly to confirm pregnancy. After calving, offspring were weighed and examined by veterinary doctors.

\section{Statistical analysis}

Rates of cleavage and blastocyst formation per zygote and rate of development after transfer to recipients were analysed by Chi-square tests. Birth weight is given 
as the mean value \pm standard deviation. Probabilities (P-values) of less than 0.05 were regarded as statistically significant and less than 0.01 as highly statistically significant.

\section{RESULTS}

The development of zygotes co-cultured with Vero or Vero/BRL cells was compared on day 2 (48 h post insemination) and on day 7 (168 h post insemination) (Table 1). On day 2 no significant differences were observed in embryo development (cleaved embryos) between the two co-culture systems.

Table 1. In vitro development of bovine embryos co-cultured with Vero and Vero/BRL cells

\begin{tabular}{lccc}
\hline Culture system & $\begin{array}{c}\text { No. of } \\
\text { zygotes }\end{array}$ & $\begin{array}{c}\text { Cleaved embryos } \\
\%\end{array}$ & $\begin{array}{c}\text { Blastocysts } \\
\%\end{array}$ \\
\hline Vero & 240 & $198(82.5)$ & $73(30.41)^{\mathrm{a}}$ \\
Vero/BRL & 238 & $201(84.45)$ & $102(42.85)^{\mathrm{b}}$ \\
\hline
\end{tabular}

ab statistical difference $(\mathrm{P} \leq 0.05)$

On day 7, a higher percentage of successfully developed blastocysts was observed on mixed co-culture - Vero/BRL cells $(42.85 \%)$, whereas a lower percentage of blastocysts was observed on Vero cells $(30.41 \%)$. The difference between Vero and Vero/BRL was statistically significant $(\mathrm{P} \leq 0.05)$.

The results of embryo transfer are presented in Table 2. On day 35, no significant difference was observed in prenatal development of embryos between Vero and Vero/BRL cells. On day 65, a higher percentage of prenatal

Table 2. The results of embryo transfer to recipients

\begin{tabular}{lccccc}
\hline $\begin{array}{l}\text { Culture } \\
\text { system }\end{array}$ & $\begin{array}{c}\text { No. of } \\
\text { transferred } \\
\text { blastocysts }\end{array}$ & $\begin{array}{c}\text { No. of } \\
\text { pregnancies } \\
\text { on day } 35, \%\end{array}$ & $\begin{array}{c}\text { No. of } \\
\text { pregnancies on } \\
\text { day } 65, \%\end{array}$ & $\begin{array}{c}\text { Calving rate } \\
\text { of offspring }\end{array}$ & $\begin{array}{c}\text { Birth weight } \\
\mathrm{x} \pm \mathrm{SD}\end{array}$ \\
\hline Vero & 72 & $31(43.05)$ & $27(37.50)^{\mathrm{a}}$ & $27(37.50)^{\mathrm{c}}$ & $32.6 \pm 3.87$ \\
Vero/BRL & 76 & $34(44.74)$ & $12(15.78)^{\mathrm{b}}$ & $10(13.16)^{\mathrm{d}}$ & $34.2 \pm 4.17$ \\
\hline $\begin{array}{l}\text { a,b,c,d } \quad \text { indicate } \\
\left({ }^{\mathrm{ab}} \mathrm{P} \leq 0.05,{ }^{\text {cd }} \mathrm{P} \leq 0.01\right)\end{array}$ & & &
\end{tabular}

development was found on Vero cells $(37.50 \%)$, whereas a lower percentage, on Vero/BRL cells (15.78\%). The difference between the two co-culture systems was statistically significant $(\mathrm{P} \leq 0.05)$. A higher calving rate was observed from embryos 
co-cultured with Vero cells (37.50\%) as compared with Vero/BRL cells (13.16\%). The difference between groups was highly statistically significant $(\mathrm{P} \leq 0.01)$. All calves were born naturally and healthy. Independent of culture system, the birth weight of all calves was similar.

\section{DISCUSSION}

Bovine embryos developed more efficiently to the blastocyst stage on Vero/ BRL cells: $42.85 \%$ (mixed co-culture) than on Vero cells: $30.41 \%$ (Table 1 ). This supports our previous results, in which the difference between the two coculture systems was similar: $40.50 \%$ on Vero/BRL cells vs $27.25 \%$ on Vero cells (Duszewska et al., 2000). Also in other studies, a lower percentage of blastocysts was obtained from co-culture of embryos with both Vero cells, about 30\% (Menck et al., 1997; Pegoraro et al., 1998) and BRL cells, about 35\% (Farin et al., 1995; Hernandez-Ledezma et al., 1996).

Somatic cells may support embryo development through two possible mechanisms. First, somatic cells could remove deleterious components from the culture medium, protect against agents of oxidative stress and/or modulate the physico-chemical conditions of the medium. Some authors suggest that Vero cells may specifically assist by metabolizing or absorbing inhibitory substances from the culture medium. Second, somatic cells may also secrete embryotrophic factors (review: Orsi and Reischl, 2007). Both Vero and BRL cells secrete many such factors, including colony stimulating factor (CSF), epidermal growth factors (EGFs), fibroblast growth factors (FGFs), insulin-like growth factors (IGFs), insulin growth factors (IGF-I and -II), interleukins (ILs), leukaemia inhibitory factor (LIF), platelet-derived growth factor (PDGF), stem cell factor (SCF) and transforming growth factors (TGF- $\alpha,-\beta_{1}$ and $-\beta_{2}$ ) (Duszewska et al., 2000).

The aim of this research was to compare the developmental potential of embryos co-cultured with Vero and Vero/BRL cells after transfer to recipients. Generally, both embryo yield and embryo quality contribute to embryo transfer efficiency (Rizos 2002). In vitro conditions during maturation of oocytes, fertilization and embryo development can lead to a short-term response and long-term consequences for prenatal and postnatal development. Altered intracellular signalling, metabolic stress, changes in gene expression, apoptosis, cell proliferation, chromosomal abnormality and epigenetic modifications may all have short-term effects. By contrast, long-term consequences of in vitro culture can include reduced implantation capacity, unbalanced foetal/placental allocation, altered maternal nutrient provision and abnormal foetal growth rate (Lonergan et al., 2006). In farm animals, these long-term consequences lead to abnormal birth weight and postnatal growth abnormality, referred to as Large Offspring Syndrome (LOS) (van Wagtgendonk et al., 2000; Bertolini et al., 2002). Sometimes, but not 
usually, LOS has been associated with in vitro production of embryos, including nuclear transfer and pronuclear injection (Young and Fairburn 2000; review: van Wagtgendonk et al., 2000; Renard et al., 2002; Duszewska et al., 2003, 2004).

In our experiment more offspring were obtained after transfer of embryos co-cultured with Vero cells (37.5\%) than with Vero/BRL (13.16\%) (Table 2). Generally, the calving rate after transfer of cultured embryos to recipients is lower (about 30-40\%) than of embryos obtained in vivo (about 70\%) (Pomar et al., 2005). However a calving rate of $13.16 \%$ after transfer of embryos co-cultured with Vero/BRL cells is drastically lower. The high pregnancy loss occurred between days 35 and 65 .

However, embryos developed better to the blastocyst stage with Vero/BRL cells than with Vero cells, but after transfer, embryos co-cultured with Vero cells developed better. The difference between co-culture systems could be explained by excessive concentrations of some growth factors and proteins in the mixed co-culture system (Vero/BRL). These results conflict with the opinion that mixed co-culture is more effective than systems using a single cell line (Orsi and Reischl, 2007).

Probably, Vero/BRL cells lead to changes in epigenetic modifications during development. Epigenetic modifications of DNA and chromatin are important for genome function during prenatal and postnatal development. Environmental factors during in vitro development, as well as oocyte maturation and possibly fertilization, can alter epigenetic modifications and thus have short- and longterm effects on development (Reik et al., 2003).

\section{CONCLUSIONS}

Vero cells better support bovine prenatal development than Vero/BRL cells. It is likely that Vero/BRL cells led to epigenetic modifications that manifested later in development and were responsible for early foetal resorption.

\section{REFERENCES}

Bertolini M., Mason J.B., Beam S.W., Carneiro G.F., Sween M.L., Kominek D.J., Moyer A.L., Famula T.R., Sainz R.D., Anderson G.B., 2002. Morphology and morphometry of in vivo- and in vitro-produced bovine conception from early pregnancy to term and association with high birth weights. Theriogenology 58, 973-994

Duszewska A.M., Reklewski Z., Pieńkowski M., Karasiewicz J., Modliński J.A., 2000. Development of bovine embryos on Vero/BRL cell monolayers (mixed co-culture). Theriogenology 54, 1239-1247

Duszewska A.M., Rosochacki S.J., Kozikova L., Cybulska M., Korwin-Kossakowski M., Waś B., Połoszynowicz J., Wicińska K., Szydlik H., 2003. The use of GFP to select bovine embryos. J. Anim. Feed Sci. 12, 71-81 
Duszewska A.M., Wojdan J., Gawron W., Lipiński D., Piliszek A., Wenta-Muchalska E., Waś B., Słomski R., Reklewski Z., 2004. Obtaining calves after transfer of the gene construct microinjected embryos (in Polish). Med. wet. 60, 1323-1325

Farin C.E., Hasler J.F., Martus N.S., 1995. Comparision of Menezo B2 and TCM-199 media for in vitro production of bovine blastocysts. Theriogenology 43, 210 (Abstr.)

Gordon I., 2003. Laboratory production of cattle embryos. In: G.J. Persley (Editor). Biotechnology in Agriculture Series, No. 27. $2^{\text {nd }}$ Edition. CABI Publishing

Hansen P., 2006. Realizing the promise of IVF in cattle - an overview. Theriogenology 65, 119-125

Hernandez-Ledezma J.J., Villanueva C., Sikes J.D., Kubisch H.M., 1996. Increasing the rate of blastocyst formation and hatching from in vitro produced bovine zygotes. Theriogenology 46, 961-969

Holm P., Booth P.J., Schmidt M.H., Greve T., 1999. High bovine blastocysts development in a static in vitro production system using SOFaa medium supplemented with sodium citrate and myoinositol with or without serum-proteins. Theriogenology 52, 683-700

Liu Z., Foote R. H., 1995. Development of bovine embryos in KSOM with added superoxide dismutase and taurine and with five and twenty percent $\mathrm{CO}_{2}$. Biol. Reprod. 53, 786-790

Lonergan P., Fair T., Corcoran D., Evans A.C.O., 2006. Effect of culture environment on gene expression and developmental characteristics in IVF-derived embryos. Theriogenology 65, 137-152

Maed A.J., Kotsuji F., Negami A., Kamitani N., Tominaga T., 1996. In vitro development of bovine embryos in conditioned media from bovine granulosa cells and Vero cells cultured in exogenous protein- and amino acid-free chemically defined. Human Tubal Fluid medium. Biol. Reprod. $54,930-936$

Marguant-Le Guienne B., Gerard M., Solari A., Thibault C., 1989. In vitro culture of bovine eggs fertilised either in vivo or in vitro. Reprod. Nutr. Develop. 29, 559-568

Menck M.C., Guyader-Joly C., Peynot N., Le Bourhis D., Lobo R.B., Renard J.P., Heyman Y., 1997. Beneficial effects of Vero cells for developing IVF bovine eggs in two different coculture systems. Reprod. Nutr. Develop. 37, 141-150

Orsi N.M., Reischl J.B., 2007. Mammalians embryos co-culture: Trials and tribulations of a misunderstood method. Theriogenology 67, 441-458

Parrish J.J., Susko-Parrish J.L., Leibfried-Rutledge M.L., Critse E.S., Eyestone W.H., First N.L., 1986. Bovine in vitro fertilisation with frozen-thawed semen. Theriogenology 25, 591-600

Pegoraro L.M.C., Thuard J.M., Delalleau N., Guerin B., Deschamps J.C., Marquant-Le Guienne B., Humblot P., 1998. Comparison of sex ratio and cell number of IVM-IVF bovine blastocysts cocultured with bovine oviduct epithelial cells or with Vero cells. Theriogenology 49, 1579-1590

Pomar F.J., Teerds K. J., Kidson A., Colenbrander B., Tharasanit T., Aguilar B., Roelen B.A.J., 2005. Differences in the incidence of apoptosis between in vivo and in vitro produced blastocysts of farm animal species: a comparative study. Theriogenology 63, 2254-2268

Reed W.A., Suh T.K., Bunch T.D., White K.L., 1996. Culture of in vitro fertilized bovine embryos with bovine epithelial cells, Buffalo Rat Liver (BRL) cells or BRL-cell-conditined medium. Theriogenology 45, 439-449

Rehman N., Collins A.R., Suh T.K., Wright R.W., 1994. Development of in vitro matured and fertilized bovine oocytes co-culture with Buffalo Rat Liver cells. Theriogenology 41, 1453-1462

Reik W., Santos F., Dean W., 2003. Mammalian epigenetics: reprogramming the genome for development and therapy. Theriogenology 59, 21-32

Renard J.P., Zhou Q., Lebourhis D., Chavatte-Palmer P., Hue I., Heyman Y., Vignon X., 2002. Nuclear transfer technologies: between successes and doubts. Theriogenology 57, 203-222

Rizos D., Ward F., Duffy P., Boland M.P., Lonergan P., 2002. Consequences of bovine oocyte maturation, fertilization or early embryo development in vitro versus in vivo: Implication for blastocysts yield and blastocysts quality. Mol. Reprod. Dev. 61, 234-248 
Rosenkranz Jr. C.F. , First N.L., 1994. Effect of free amino acids and vitamins on cleavage and developmental rate of bovine zygotes in vitro. J. Anim. Sci. 72, 434-437

Van Wagtendonk-de Leeuw A.M., Mullaart E., de Roos A.P. W., Merton J.S., Den Daas J.H.G., Kemp B., De Ruigh L., 2000. Effects of different reproduction techniques: AI, MOET or IVP on health and welfare of bovine offspring. Theriogenology 53, 575-597

Young L.E., Fairburn H.R., 2000. Improving the safety of embryo technologies: possible role of genomic imprinting. Theriogenology 53, 627-648 